* Doutorando (com bolsa financiada pela CAPES) e Mestre em Direito Público (com bolsa financiada pela $\mathrm{CNPq}$ ) pela Universidade do Vale do Rio dos Sinos (UNISINOS), sob orientação do Prof. Dr. Lenio Luiz Streck. Membro do grupo de pesquisa Hermenêutica Jurídica, vinculado ao $\mathrm{CNPq}$, e do grupo DASEIN - Núcleo de Estudos Hermenêuticos, ambos liderados por seu orientador. Bacharel em Direito pela Faculdade de Direito de Franca (FDF). Tem experiência na área de Direito Público, atuando principalmente nos seguintes temas: Direito Constitucional e Teoria da Constituição; Teoria do Estado; Filosofia do Direito e Hermenêutica Jurídica. E-mail: danilolimapt@yahoo.com.br

\section{O leviatã e as guerras religiosas do século XVII: uma análise do estado absolutista a partir de Thomas Hobbes}

\author{
THE LEVIATHAN AND THE RELIGIOUS WARS OF \\ THE SEVENTEENTH CENTURY: AN ANALYSIS OF THE \\ ABSOLUTIST STATE FROM THOMAS HOBbES
}

* Danilo Pereira Lima

Resumo: Reconhecido atualmente como um dos principais teóricos da filosofia política do século XVII, Hobbes teve seu pensamento envolvido nas principais guerras religiosas e políticas, que, naquele período, ameaçavam dissolver a incipiente organização estatal inglesa. Desse modo, o presente trabalho pretende analisar os principais acontecimentos políticos, sociais e filosóficos, que, de alguma maneira, acabaram influenciando o pensamento hobbesiano acerca da formação do Estado absolutista, pois, para ele, onde não havia poder comum não poderia prevalecer à lei e a ordem, mas apenas a morte, o caos e a destruição.

Palavras-chave: Absolutismo; Estado; Modernidade; Contratualismo; Subjetivismo.

Abstract: Currently recognized as one of the leading theorists of political philosophy of the seventeenth century, Hobbes had his thinking involved in major political and religious wars, which, at that time, threatened to dissolve the nascent British state organization. Thus, this study aims to analyze the major political, social and philosophical events that somehow ended up influencing the Hobbesian thinking about the formation of the absolutist state, since for him, where there were no common power could not prevail the law and order, but only death, chaos and destruction.

Keywords: Absolutism; State; Modernity; Contractualism; Subjectivism. 


\section{INTRODUÇÃO}

O seu coração é firme como uma pedra e firme como a mó de baixo. Levantandose ele, tremem os valentes; em razão dos seus abalos se purificam. Se alguém lhe tocar com a espada, essa não poderá penetrar, nem lança, dardo ou flecha (JÓ, 2004, p. 530).

O Estado moderno nasceu primeiramente como Estado absolutista, ao apresentar uma resposta aos diversos problemas e contradições que surgiram após a desintegração da sociedade feudal. Segundo Raymundo Faoro (2001, p. 37-38):

[...] o advento de uma economia monetária, a ascendência do mercado nas relações de troca e a existência de navegações comerciais durante a idade média, acabaram prejudicando o desenvolvimento do feudalismo em Portugal, que acabou por desenvolver um modelo de dominação política patrimonialista e estamental, centralizado na figura do monarca. Assim, ao reforçar a tese da inexistência do feudalismo em Portugal, ou, mais longinquamente, na Península Ibérica, defendida primeiramente por Alexandre Herculano, ele afirma que: "O feudalismo, acidente político e de direito público, não se configura, historicamente, sem que reúna os elementos que o fazem um regime social. O argumento de que se deve procurar-lhe o cerne no sistema econômico, no enquadramento das forças de produção, peca por uma fraqueza fundamental. Se ele não logrou provocar, na superfície, as florações sociais, jurídicas e institucionais - as chamadas superestruturas -, essa incapacidade denuncia a própria incerteza da infra-estrutura, da base". Assim, ao contrário das interpretações marxistas, que compreendem a formação do sistema político como um mero reflexo do sistema econômico, Faoro ampliou a análise da formação histórica do Estado moderno buscando compreender o sistema político a partir dele mesmo.

Durante a idade média, o feudalismo destacou-se como uma unidade orgânica de economia e dominação política, baseada em uma cadeia de soberanias parcelares na qual o exercício do poder político encontrava-se completamente fragmentado. ${ }^{1}$

\footnotetext{
${ }^{1}$ É necessário destacar que o historiador Perry Anderson, a partir de uma abordagem marxista, analisou a formação do Estado absolutista como mera expressão dos interesses políticos e econômicos da aristocracia, que, ao criar um poder político centralizado, apenas buscou assegurar seu próprio domínio social frente à decadência do modelo de dominação (servidão) presente no modo de produção feudal (ANDERSON, 2004).
} 
Segundo ele:

Com a comutação generalizada das obrigações, transformadas em rendas monetárias, a unidade celular de opressão política e econômica do campesinato foi gravemente debilitada e ameaçada de dissociação (o final deste processo foi o 'trabalho livre' e o 'contrato salarial'). O poder de classe dos senhores feudais estava assim diretamente em risco com o desaparecimento gradual da servidão. O resultado disso foi um deslocamento da coerção político-legal no sentido ascendente, em direção a uma cúpula centralizada e militarizada - o Estado absolutista. Diluída no nível da aldeia, ela tornou-se concentrada no nível 'nacional' (ANDERSON, 2004, p. 19).

Assim, é possível perceber que, para o historiador Perry Anderson, a formação do Estado absolutista foi, principalmente, resultado das contradições geradas pela estrutura econômica medieval (fim da servidão) e pelo desenvolvimento da luta de classes. (ANDERSON, 2004).

Não havia Estado, apenas a Igreja possuía certa unidade institucional, o que acabou favorecendo seu domínio político. As relações sociais, entre os membros da aristocracia, eram marcadas essencialmente pelo dever de vassalagem e de serviço militar, exercidas diretamente pelos senhores feudais. A aristocracia não trabalhava diretamente em suas terras e dedicavase exclusivamente as atividades militares, enquanto, do outro lado, o servo estava ligado permanentemente a terra, sendo obrigado a trabalhar alguns dias da semana apenas para pagar as obrigações devidas ao seu senhor.

No início da idade moderna essas relações sociais se desestruturaram completamente, colocando em crise toda a estrutura política, econômica e social do feudalismo. Segundo Nicola Matteucci, essa crise do complexo modelo de organização feudal foi motivada por distintos fatores: o crescimento econômico, que favoreceu o nascimento das novas classes sociais e o rompimento com o estático equilíbrio da sociedade esta mental; a nova cultura humanista, que passou a situar o indivíduo no centro do mundo, tornando-o insensível diante de uma ordem social natural correspondente a uma ordem celeste; e o surgimento do Estado, que se afirmou como uma máquina construída racionalmente (MATTEUCCI, 1998).

Nesse sentido, o Estado absolutista surgiu para superar a ultrapassada estrutura social e política do medievo, colocando-se em um nível superior 
em comparação com qualquer instituição existente naquela época, já que a monopolização do poder político e da força militar permitiu uma maior uniformidade legislativa e administrativa frente às várias formas particularistas de exercício do poder político. ${ }^{2}$ Com a formação de um moderno quadro burocrático e um exército regular, o Estado absolutista se transformou no único sujeito político com capacidade para regular o comportamento dos indivíduos e das forças sociais, oferecendo melhores condições para a pacificação interna e externa. Assim, foi a partir das turbulências políticas medievais, com a Guerra das Rosas, a Guerra dos Cem Anos e a segunda Guerra Civil de Castela, que as primeiras monarquias absolutistas foram erguidas, com os reinados de Luis XI, na França, Fernando e Isabel, na Espanha, Henrique VII, na Inglaterra, e Maximiliano, na Áustria (ANDERSON, 2004).

É preciso destacar que essa transição, do medievo para a idade moderna, não ocorreu de maneira tranquila. No século XVI a ordem estabelecida pelo feudalismo entrou em plena decadência e o fim da unidade da Igreja Católica, a partir da reforma protestante, ${ }^{3}$ acabou por agravar ainda mais o quadro de extrema violência desse período. Diversas facções religiosas passaram a se digladiar, deixando a sociedade em uma anarquia generalizada de guerras civis, duelos e assassinatos. De acordo com Reinhart Koselleck, "[...] a pluralização da Ecclesia Sancta foi um fermento para a depravação de tudo o que antes era coeso: famílias, estamentos, países e povos" (KOSELLECK, 1999, p. 21).

A instabilidade social, criada pelos partidos religiosos e igrejas intolerantes, exigia uma solução capaz de apaziguar essas lutas. Somente um poder político e militar, colocado acima das opiniões dos súditos, teria condições reais para pacificar os homens. Desse modo, a solução elaborada pelos teóricos do Estado absolutista ocorreu no sentido de romper com a prevalência de qualquer facção religiosa sobre os interesses estatais, partindo da submissão

${ }^{2}$ Matteucci destaca que esta modalidade de Estado, definida como absoluto por seus teóricos, não deve(ria) ser tratada como arbitrária ou despótica, já que prevalecia nela à lógica da racionalidade técnica e não o mero capricho do monarca. O poder do rei era indivisível e incontrolável, mas, ao mesmo tempo, limitado, pois o rei deveria governar e decidir apenas depois de ouvir o parecer dos órgãos institucionais com funções específicas (MATTEUCCI, 1998).

3 Durante este período, a Inquisição foi reorganizada principalmente para combater a reforma protestante. Desse modo, segundo o historiador Francisco Bethencourt, entre as justificativas presentes na bula Licet ab initio, responsável pela reorganização dos trabalhos do Santo Ofício em Roma, constava a motivação de combater as ameaças constantes de ruptura da unidade da Igreja Católica. (BETHENCOURT, 2000). 
dos diferentes partidos religiosos a uma única autoridade soberana, ${ }^{4}$ já que, tanto no plano interno, como no plano externo, o Estado não reconheceria nenhuma instancia superior a própria ordem estabelecida por ele. Nesse mesmo sentido, Nicola Matteucci afirma que,

En el quinientos, sin embargo, la paz social no se identifica ya con la recta administración de la justicia por el rey, sino con la necesidad de superar una guerra civil surgida por motivos religiosos. Era necesaria la primacía de la política y del Estado (una unidad superior y neutral), y del orden mundano que éste representaba, sobre sectas religiosas intolerantes que provocaban desordenes en nombre de la primacía de la religión; se necesitaba crear um campo de acción racional en el que todo - de la religión a la economía - fuese juzgado con base en la utilidad del Estado, con base en um frio cálculo racional de las consecuencias de cada acción (MATTEUCCI, 1998, p. 31).

Assim, diante dessas pressões do novo ambiente social, as mudanças políticas acabaram conduzindo o Estado a uma incipiente racionalização, motivado principalmente pela grande insuficiência dos velhos instrumentos políticos para satisfazer as novas demandas diplomáticas, militares e financeiras. A formação dos exércitos regulares exigiu maiores recursos financeiros, já que os Estados tornavam-se verdadeiras máquinas de guerra, ao voltar boa parte das suas operações para os campos de batalha. Era uma situação que exigia um sistema fiscal muito mais eficiente e organizado. Desse modo, a construção de uma estrutura burocrática para realizar a tributação entre os súditos e arrecadar maiores recursos financeiros foi fundamental para a cobertura das novas despesas militares. Todavia, é preciso destacar que essa necessária

\footnotetext{
${ }^{4}$ Foi Jehan Bodin que primeiramente definiu o conceito de soberania, elaborando uma verdadeira resposta contra as investidas dos monarcômacos do século XVI. A partir desta definição, o poder soberano não se submeteria a nenhuma outra instituição concorrente dentro ou fora do reino, já que, segundo este conceito criado por Bodin, apenas o soberano possuía capacidade para criar e suprimir uma lei, decretar a guerra e tratar a paz, instituir os principais oficiais, julgar em última instância, outorgar perdão aos condenados acima das sentenças e contra o rigor das leis, cunhar moedas, suspender derramas e impostos. No entanto, esta soberania não deve(ria) ser confundida com qualquer forma de governo arbitrário, pois da mesma forma que os súditos estariam sujeitos as leis criadas pelo soberano, o poder soberano sempre estaria sujeito as leis estabelecidas pelo direito natural. Para Bodin, a soberania poderia recair tanto numa multidão (democracia) ou em uma minoria (aristocracia), quanto em um só homem (monarquia), mas sua preferência sempre foi pela monarquia, única forma de governo capaz de derrotar os poderes particularistas existentes no feudalismo e derrotar a teoria concorrente do governo misto, defendida principalmente por escritores protestantes. É importante ressaltar que esse conceito de soberania foi fundamental para o desenvolvimento da filosofia política, tornando-se um conceito central na ciência política e no direito público. (CHEVALLIER, 1999).
} 
racionalização, da atividade administrativa, não chegou a atender os requisitos propostos por Max Weber, no sentido de constituir uma administração racionallegal, ${ }^{5}$ mas, ao contrário, o que predominou foi uma noção privada do cargo público, onde a ocupação do mesmo ocorria principalmente por meio de negociações de compra e venda.

Foi nesse contexto que Thomas Hobbes escreveu o Leviatã, obra fundamental para a compreensão do Estado absolutista. Considerado hodiernamente como um dos principais teóricos da filosofia política do século XVII, Hobbes teve seu pensamento influenciado grandemente pelas guerras religiosas e políticas, que, naquela conjuntura, ameaçavam dissolver a incipiente organização estatal inglesa. Nesse sentido, ao defender a ideia de um poder exercido de forma absoluta, acima das contradições políticas e religiosas, Hobbes não defendeu uma monarquia absolutista baseada na teoria tradicional do direito divino do monarca, ${ }^{6}$ mas sim o fortalecimento de uma organização estatal secularizada, com condições de alcançar o máximo de eficiência na pacificação social, pois, segundo ele, onde não havia poder comum não haveria lei e ordem (HOBBES, 1979). Como é possível perceber, o pensamento de Hobbes foi marcado por uma concepção negativa da natureza humana, não no mesmo sentido do pensamento medieval, mas por considerar o homem naturalmente agressivo e belicoso, sempre entregue as paixões e as vaidades por glória e poder, o que, para ele, tornava extremamente necessária a construção de um

\footnotetext{
${ }^{5}$ De acordo com Max Weber, uma administração racional-legal deve organizar a burocracia como uma camada profissional, capaz de assegurar o bom funcionamento do Estado e da administração pública. Desse modo, a burocracia não deveria invadir e dirigir a esfera econômica, política e financeira, mas, pelo contrário, deveria aparecer como um aparelhamento neutro em qualquer tipo de Estado ou em qualquer forma de organização do poder, permitindo a realização do serviço público de maneira profissional e técnica, para se distanciar das influências político-partidárias. Assim, nos termos de Weber, a burocracia deveria apenas ordenar o comportamento humano, por meio do exercício da autoridade racional-legal, e, ao mesmo tempo, buscar o atendimento de objetivos organizacionais gerais, a partir de uma rigorosa divisão de tarefas, com a criação de regras detalhadas e a formação de uma hierarquia para garantir sua execução (WEBER, 2004).

${ }^{6} \mathrm{Um}$ dos maiores expoentes da teoria da origem divina do poder monárquico foi Bossuet, no século XVII. Ao falar da origem do governo civil, primeiramente Bossuet partiu da tese aristotélica da natureza política do homem (o homem como animal político), para depois chegar à tese hobbesiana do homem lobo do homem, que, segundo ele, teve origem a partir do acontecimento bíblico do pecado original, praticado por Adão e Eva. Para Bossuet, o pecado original foi o responsável por ter transformado a vida numa verdadeira anarquia, fazendo prevalecer à insociabilidade entre os homens. Desse modo, ele acreditava que apenas com a constituição de um governo civil seria possível garantir o estabelecimento da paz e da segurança. Para melhor cumprir esta função, Bossuet defendeu a monarquia absolutista como a forma mais adequada de governo, já que qualquer tipo de divisão, no exercício do poder, era considerado por ele como o principal mal dos Estados. Assim, esta forma de governo defendida por Bossuet, estava fundamentada inteiramente na sagrada escritura, com os monarcas reconhecidos como verdadeiros ministros de Deus, ao deter todo poder necessário a manutenção da ordem e da paz social. (CHEVALLIER, 1999).
} 
Estado Leviatã com condições de impor a estabilidade política. Por isso, numa passagem da obra, ele chegou a afirmar que:

O fim último, causa final e desígnio dos homens (que amam naturalmente a liberdade e o domínio sobre os outros), ao introduzir aquela restrição sobre si mesmos sob a qual os vemos viver nos Estados, é o cuidado com sua própria conservação e com uma vida mais satisfeita. Quer dizer, o desejo de sair daquela mísera condição de guerra que é a consequência necessária (conforme se mostrou) das paixões naturais dos homens, quando não há um poder visível capaz de os manter em respeito, forçando-os, por medo do castigo, ao cumprimento de seus pactos e ao respeito àquelas leis da natureza [...] (HOBBES, 1979, p. 103).

Desse modo, o presente trabalho passará por todas essas questões, na tentativa de melhor compreender a elaboração teórica do Estado Leviatã, de Thomas Hobbes, já que, durante muito tempo, seu pensamento ficou obscurecido por interpretações equivocadas, que chegaram a considerá-lo como escritor "maldito" ou mesmo um filósofo menor da escola empirista inglesa (BOBBIO, 1991, p. 185). Para isso, o trabalho pretende analisar os principais acontecimentos políticos, sociais e filosóficos, que, de alguma maneira, acabaram influenciando suas reflexões acerca da formação do Estado moderno. Esse Estado Leviatã, proposto por ele, surgiu num contexto em que a Inglaterra encontrava-se completamente dividida pela guerra civil, com o rei Carlos I decapitado e um governo autoritário liderado por Oliver Cromwell. Ao mesmo tempo, as transformações ocorridas na filosofia, a partir da modernidade, foram de fundamental importância para a construção teórica do Leviatã. A superação da metafísica clássica pela metafísica moderna deixou marcas importantes no pensamento filosófico de Hobbes, principalmente a partir das influências recebidas do racionalismo, de René Descartes, do empirismo, de Francis Bacon, do nominalismo inglês, de Guilherme de Ockham e da ciência moderna, com Galileu Galilei (SANTOS, 2009). Portanto, todos esses elementos serão considerados ao longo deste trabalho, para que o Estado Leviatã, de Thomas Hobbes, seja devidamente compreendido.

\section{UMA BREVEANÁLISE DOS CONFLITOS SÓCIO-POLÍTICOS DO SÉCULO XVII}

Durante o século XVII, período em que Thomas Hobbes se dedicou a refletir e a elaborar respostas para os problemas que afetavam o estabelecimento 
do poder estatal, a Inglaterra passou por diversos conflitos sócio-políticos dominados por duas vertentes: as disputas entre o rei e os tribunais e, ao mesmo tempo, as disputas entre o rei e o parlamento. No primeiro caso, Edward Coke e Thomas Hobbes produziram um importante debate acerca das tentativas dos reis Jaime I e Carlos I (da dinastia Stuart) de impor aos juízes a preeminência do direito estatutário sobre o common law. Desse modo, em defesa do direito estatutário, Hobbes combateu as principais ideias de Coke, ao afirmar a exclusividade do soberano no momento de pôr o direito. ${ }^{7}$ Assim, segundo Norberto Bobbio (2006, p. 33):

[...] o rei, ao exercer o jurisdictio (através de seus juízes) era obrigado a aplicar a common law; esta última, portanto, limitava o poder do soberano. Isto explica por que a monarquia inglesa nunca deteve um poder ilimitado (diferentemente das monarquias absolutas continentais), porque na Inglaterra fora desenvolvida a separação dos poderes (transferida depois na Europa graças à teorização executada por Montesquieu) e porque tal país é a pátria do liberalismo (entendido como a doutrina dos limites jurídicos do poder do Estado)

Já no segundo caso o conflito foi motivado principalmente por uma forte disputa política entre a prerrogativa do rei (que a dinastia Stuart procurava estender cada vez mais) e o poder de legislar exercido pelo parlamento, que, nesse mesmo período, começava a se colocar como um autêntico representante da nação, ao não aceitar as investidas do monarca contra sua esfera de atuação. Mais tarde, esses conflitos entre o rei e o parlamento acabaram desembocando em uma violenta guerra civil, acompanhada pelo olhar atento de Thomas Hobbes, que, com sua teoria a respeito do Estado Leviatã (1651), buscou uma solução para os conflitos sócio-políticos existentes em sua época. ${ }^{8}$

Para melhor compreender o cenário institucional dessas disputas políticas, do século XVII, é importante levar em consideração as transformações pelas quais o parlamento e a monarquia passaram ao longo do seu desenvolvimento histórico. Assim, diferentemente do continente, na Inglaterra medieval já havia

\footnotetext{
Na Inglaterra o direito da common law acabou tomando a primazia sobre o direito estatutário (BOBBIO, 2006).

8 Apesar da importância constitucional do debate entre os defensores da common law e do direito estatutário para o desenvolvimento do direito inglês, no presente capítulo o trabalho vai abordar principalmente as disputas políticas entre a monarquia e o parlamento, que, no final da primeira metade do século XVII, acabaram por levar a Inglaterra a uma violenta Guerra Civil, tornando-se um acontecimento fundamental para a compreensão do Estado Leviatã elaborado por Thomas Hobbes.
} 
uma monarquia feudal muito poderosa, com uma precoce centralização administrativa, determinada fundamentalmente pela primitiva conquista militar normanda e pela modesta extensão territorial do país, já que em todo território inglês praticamente inexistiam potentados territoriais semi-independentes e cidades com total autonomia política. ${ }^{9}$

Assim, segundo Raymundo Faoro, a condição política existente naquela época era a seguinte:

[...] entre o rei e os súditos não há intermediários: um comanda e todos obedecem. A recalcitrância contra a palavra suprema se chamará traição, rebeldia à vontade que toma as deliberações superiores. $\mathrm{O}$ chefe da heterogênea hoste combatente não admite aliados e sócios: acima dele, só a Santa Sé, o papa e não o clero; abaixo dele, só há delegados sob suas ordens, súditos e subordinados (FAORO, 2001, p. 19).

Contudo, todas essas condições sócio-políticas, indicativas para a formação de uma monarquia fortemente centralizadora, não foram capazes de assegurar o desenvolvimento do maior e mais forte Estado absolutista europeu na Inglaterra, já que as disputas políticas entre a monarquia e o parlamento, acompanhadas das guerras religiosas, acabaram antecipando uma revolução burguesa na ilha. Por essa razão, logo no início do livro Crítica e crise, Reinhart Koselleck registrou algumas diferenças entre os processos de formação e derrocada do absolutismo inglês e do continente. O autor afirma que a guerra civil religiosa, travada em solo inglês, foi responsável pela completa destruição do Estado absolutista, significando, ao mesmo tempo, uma autêntica revolução burguesa; enquanto isso, no caso do continente, a superação das guerras religiosas representou o marco inicial da formação dos Estados absolutistas, que, somente mais tarde, alcançariam uma revolução burguesa, a partir do impacto político dos acontecimentos revolucionários da França de 1789 (KOSELLECK, 1999).

Por outro lado, juntamente com essa precoce centralização monárquica, a organização política inglesa também desenvolveu um tipo complementar de representação da aristocracia, numa espécie de parlamento, que, excepcionalmente, era responsável apenas por votar a ajuda econômica e política prestada ao monarca. A existência dessa instituição não constituía uma

${ }^{9}$ Logo após a guerra de reconquista, Portugal também gerou uma forte centralização política, com a ascensão de um monarca com grande poder militar e senhor de imensas terras (FAORO, 2001, p. 19).

REVISTA DO DIREITO PÚBLICO, Londrina, v.10, n.1, p.9-30, jan./abr.2015 
peculiaridade nacional, já que em outros lugares da Europa também havia instituições representativas dos interesses da aristocracia. No entanto, o parlamento inglês diferenciou-se completamente de seus congêneres do continente no seguinte sentido: em primeiro lugar, por ter se constituído como único parlamento representativo dos interesses aristocráticos em todo seu território e, em segundo lugar, pela completa inexistência de uma divisão tripartida no seio de sua própria organização (entre nobres, clero e burgueses). (ANDERSON, 2004).

Portanto, o desenvolvimento dessa precoce centralização monárquica paradoxalmente gerou um parlamento unitário entre os ingleses, que, consequentemente, acabou se transformando em um importante instrumento de limitação negativa do poder legislativo do rei. Foi nesse sentido que, após o reinado de Eduardo I, o parlamento passou a controlar a aprovação de qualquer estatuto elaborado pelo rei, numa situação em que, embora o poder monárquico fosse maior entre os ingleses do que entre os franceses do século XVI, a relativa autonomia usufruída pelos reis franceses nunca chegou a ser desfrutada completamente pelos reis ingleses.

No início da idade moderna o parlamento chegou a sofrer certo refluxo com a ascensão de Henrique VII ao trono inglês. De fato, durante o período que antecedeu a Guerra das Rosas (1453 - 1485), ${ }^{10}$ o parlamento ainda era convocado anualmente, mas, com a consolidação de seu governo, esta instituição deixou de ser convocada durante um bom tempo, voltando a se reunir apenas uma vez nos últimos doze anos de seu reinado (1497 - 1509). Essa não convocação não chegou a ocasionar sua completa destruição. Na verdade, esse distanciamento com relação ao parlamento ocorreu no momento em que Henrique VII buscava a sujeição dos grandes aristocratas, ao limitar seus privilégios privados por meio do exercício da prerrogativa real. ${ }^{11}$ Assim, segundo

\footnotetext{
${ }^{10}$ A Guerra das Rosas (1453 - 1485) foi um conflito político entre duas casas da aristocracia inglesa (os York e os Lancaster) pela posse do trono. De fato, após a perda de territórios importantes para a França, durante a Guerra dos Cem Anos, a unidade política entre os membros da aristocracia ficou enfraquecida, fazendo com que o trono fosse ocupado durante trinta anos de maneira alternada pelas duas casas. Assim, diante dessa instabilidade política, o parlamento deixou de ser convocado durante toda a guerra e apenas retornou nos primeiros dez anos após o encerramento do conflito, para ser novamente esquecido pelo rei Henrique VII (da dinastia Tudor) nos seus últimos doze anos de reinado (1497 a 1509).

${ }^{11}$ Apesar do forte movimento de centralização política que ocorreu no século XVI, com a dinastia Tudor, o termo absoluto, aplicado ao monarca deste período, ainda não se encontrava completamente livre das restrições legais existentes naquela época. Foi apenas com a ascensão da dinastia Stuart, a partir do século XVII, que o termo absoluto passou a qualificar um poder exercido de forma soberana pelo monarca, que, neste período, buscava se colocar acima do parlamento. (RIBEIRO, 1984).
} 
Renato Janine Ribeiro:

A prerrogativa fora, sob os Tudor, uma reserva ampla de poder à disposição do rei, conferindo-lhe o arbítrio necessário a executar as leis, a definir uma política, a agir com presteza. Com os Stuart este importante resíduo transformase em fonte do poder: a prerrogativa fundamenta o que agora se chama poder absoluto do rei (RIBEIRO, 1984, p. 134).

Nesse sentido, a virada para o século XVI representou um início promissor na construção do Estado absolutista inglês, com a reorganização de sua estrutura política logo após o encerramento das disputas pelo trono.

Este processo chegou a acarretar um significativo aumento na concentração do poder exercido pelo monarca, numa situação muito semelhante ao que estava acontecendo na França daquela época. No entanto, as várias semelhanças com o caso francês não devem ocultar uma deficiência fundamental para o amadurecimento do Estado absolutista na Inglaterra: a ausência de um aparelho militar permanente, comandado diretamente pelo rei. Outrossim, no plano externo as coisas acabaram não ocorrendo muito bem, já que a falta de um exército moderno, adequado a nova conjuntura europeia, consequentemente deixou a Inglaterra numa posição secundária em comparação às conquistas militares espanholas e francesas. Assim, com a ascensão da dinastia Stuart no início do século XVII, essa mesma deficiência veio a impedir que a monarquia inglesa acompanhasse o processo de fortalecimento do absolutismo europeu, que, durante esse mesmo período, alcançava grande avanço político com o decrescimento da liberdade dos súditos e o fechamento ou não convocação de diversos parlamentos.

No início do século XVII a dinastia Stuart buscou a concretização dos ideais da realeza absolutista, que, naquela época, havia se transformado numa regra comum em todas as cortes da Europa ocidental. Desse modo, algumas teorias absolutistas, baseadas no direito divino, procuraram legitimar em Deus todos os atos políticos praticados pelos monarcas. Nesse sentido, entre $1603 \mathrm{e}$ 1640, o reino acabou dividido fundamentalmente em duas posições: de um lado os defensores da prerrogativa real, com uma interpretação mais extensiva dos poderes do rei; do outro lado o parlamento, colocando-se cada vez mais como representante da nação, ao buscar novos instrumentos políticos e jurídicos para um controle mais efetivo da atuação do monarca, já que durante toda a história institucional inglesa a atuação do parlamento havia ficado restrita maiormente a questões fiscais (aumento de impostos), devendo funcionar apenas nos 
momentos de convocação realizada pelo monarca. Assim, no final da década de 1630, as guerras com a Escócia e a Irlanda elevaram esse confronto ao seu ápice, com a deflagração de uma violenta guerra civil na qual, juntamente com as divergências políticas existentes entre o parlamento e a monarquia, somouse o fanatismo dos partidos religiosos de católicos, anglicanos, presbiterianos e puritanos. O final desse conflito teve como resultado a ascensão de Oliver Cromwell, como lord protetor da Inglaterra, e a decapitação do rei Jaime I. ${ }^{12}$ Foi nesse ambiente político conturbado que Thomas Hobbes apresentou o Leviatã (1651), obra fundamental para o desenvolvimento da filosofia política na modernidade. Nela, o Estado foi apresentado como produto da razão, ${ }^{13}$ construído artificialmente pelos indivíduos para preservar o maior bem existente entre eles, que é a vida, pois, segundo Hobbes

[...] durante o tempo em que os homens vivem sem um poder comum capaz de os manter a todos em respeito, eles se encontram naquela condição a que se chama guerra; e uma guerra que é de todos os homens contra todos os homens (HOBBES, 1979, p. 75).

Por isso, ao contrário de Aristóteles ${ }^{14}$, a sociedade política hobbesiana não foi apresentada como uma organização natural, mas sim como fruto de um pacto voluntário entre os homens.

Giovane Reale e Dario Antiseri afirmam que:

O bem do indivíduo é da mesma natureza que o bem da Cidade, mas este 'é mais belo e mais divino' porque se amplia da dimensão do privado para a dimensão do social, para a qual o homem grego era particularmente sensível, porquanto concebia o indivíduo em função da Cidade e não a Cidade em função do indivíduo. Aristóteles, aliás, dá a esse modo de pensar dos gregos uma expressão paradigmática, definindo o próprio homem como 'animal

\footnotetext{
${ }^{12}$ Hobbes demonstra toda sua preocupação com os efeitos da guerra civil inglesa, numa passagem do Leviatã, onde o problema da degeneração de alguns Estados, atacados gravemente por conflitos internos, é citado categoricamente por ele: "Seja como for, é fácil conceber qual seria o gênero de vida quando não havia poder comum a recear, através do gênero de vida em que os homens que anteriormente viveram sob um governo pacífico costumam deixar-se cair, numa guerra civil". (HOBBES, 1979, p. 76).

${ }^{13}$ De acordo com Lenio, o Leviatã hobbesiano está envolvido numa postura voluntarista própria da modernidade e, por isso, ele chega a afirmar que: “[...] em síntese, é o triunfo da vontade humana, questão que se perceberá no contrato de Hobbes, em que é a vontade dos homens que faz com que consigam vencer a barbárie". (STRECK, 2011, p. 167).

${ }^{14}$ Para Aristóteles a sociedade política era um fato natural, pois o homem era apresentado por ele como um animal político naturalmente sociável. Assim, a respeito de Aristóteles e do pensamento político da Grécia antiga.
} 
político’ (ou seja, não simplesmente como animal que vive em sociedade, mas como animal que vive em sociedade politicamente organizada) [...]. (REALE; ANTISERI, 1990a, p. 208).

Por meio desse contrato os homens naturais deveriam se constituirem sociedade política, ao transferir ao soberano o direito de exercer todo o poder. Para isso, Hobbes propôs a formação de uma sociedade política com um poder soberano indivisível e integral, já que o surgimento de um governo misto, com o poder exercido de maneira completamente fragmentada, poderia colocar em risco a existência do Estado Leviatã. Para que o poder soberano tivesse condições de se impor, Hobbes defendeu que a realização do pacto deveria ocorrer apenas entre os homens naturais, deixando unicamente de fora aquele que mais tarde ficaria encarregado de exercer o poder soberano.

Por esse motivo, todos os indivíduos deveriam abrir mão de seus respectivos direitos naturais, pois a preservação de uma pequena parte deles colocaria em risco a paz e a segurança oferecidas pelo Estado. Assim, com a formação da sociedade política, a liberdade de todos os súditos deveria ser transferida imediatamente para o Estado Leviatã (que pode ser governado por um homem ou por uma assembléia), instituído como detentor de todo poder necessário para impedir a guerra entre os indivíduos, pois o enfraquecimento ou a ausência de autoridade absoluta e indivisível poderia colocar em risco as estruturas fundamentais do Estado e impedir a manutenção da paz social. Diante da constante exposição ao perigo de morte violenta, o Estado Leviatã foi elaborado essencialmente para pacificar as relações humanas, por meio da atuação de um poder soberano colocado acima das contradições políticas e religiosas daquele tempo tão conturbado. ${ }^{15}$ Dessa forma, segundo Thomas Hobbes:

[...] pela arte é criado aquele grande Leviatã a que se chamaEstado, ou Cidade (em latim Civitas), que não é senão um homem artificial, embora de maior estatura e força do que o homem natural, para cuja proteção e defesa

\footnotetext{
${ }^{15}$ Em certo sentido Chevallier considera a teoria hobbesiana fria e utilitária, pois diante da derrota do soberano numa guerra civil ou estrangeira, Hobbes chegou a defender o direito dos súditos se unirem ao vencedor para obter deste a proteção e segurança necessárias a manutenção da paz, já que o soberano derrotado não teria mais condição de cumprir este objetivo.Talvez isso explique um pouco da má fama de Hobbes entre os realistas após a publicação do Leviatã. Dessa forma, Chevallier afirma que: 'Hobbes, nas últimas páginas do Leviatã, em seu 'Retrospecto e Conclusão', realmente parece fazer, de tal doutrina, uma aplicação de todo concreta e oportuna aos Stuarts destronados e a Cromwell vencedor". (CHEVALLIER, 1999, p. 78).
} 
foi projetado. E no qual a soberania é uma alma artificial, pois dá vida e movimento ao corpo inteiro; [...] a justiça e as leis, uma razão e uma vontade artificiais; a concórdia é a saúde; a sedição é a doença; e a guerra civil é a morte (HOBBES, 1979, p. 5).

Nesse sentido, o conceito de vontade foi essencial para a elaboração do Estado Leviatã e surgiu ainda na idade média, a partir da radicalização da noção da onipotência de Deus entre os franciscanos. Segundo a posição sustentada por esta ordem religiosa, Deus não deveria ser considerado como razão, mas como amor, o que, consequentemente, tornava fundamental a compreensão de sua vontade para uma definição mais precisa do bem e do mal. Desse modo, não haveria bem ou mal em si mesmo, mas apenas o bem ou o mal definidos conforme a vontade divina (LOPES, 2009). Mais tarde, esse mesmo conceito tornou-se extremamente importante para o desenvolvimento da filosofia política, tendo grande relevância na construção de uma teoria do direito dos soberanos e também na formação dos primeiros Estados absolutistas. Isso pode ser observado claramente no contratualismo hobbesiano, onde o Estado Leviatã foi apresentado como uma criação artificial, manifestada diretamente pela vontade dos homens naturais, que, por meio da total renúncia de seus respectivos direitos naturais, acabavam transferindo ao soberano o direito de impor sua própria vontade contra todos os membros da sociedade política.

Toda essa problemática da dissolução do poder estatal, presente na Inglaterra do século XVII, foi fundamental para a elaboração do Estado Leviatã, uma organização política produzida pela razão e constituída de acordo com a vontade dos homens amedrontados pela violência daquele tempo. Apesar de nunca ter atuado como um político militante, Hobbes escreveu e pensou principalmente sobre a política do seu tempo, partindo dos problemas sóciopolíticos que prejudicavam a unidade do poder estatal. Segundo Hobbes, esse ambiente de guerra generalizada, chamado por ele de estado de natureza, ${ }^{16}$ deixava todos os homens completamente impedidos de realizar qualquer atividade que servisse ao seu próprio desenvolvimento, já que a insegurança e o constante risco de perder a vida apresentavam-se como forte obstáculo a concretização

\footnotetext{
${ }^{16}$ É importante ressaltar que o estado de natureza foi uma metáfora utilizada por Thomas Hobbes para retratar a instabilidade política e a situação de insegurança presentes em certos ambientes sociais. Desse modo, o estado de natureza poderia ser encontrado em três situações: numa sociedade pré-estatal, presente principalmente em sociedades primitivas; numa sociedade antiestatal, presente em sociedades onde o Estado já existe, mas, diante de uma situação de guerra civil, encontra-se gravemente fragilizado; e numa sociedade interestatal, que ocorre no plano internacional, já que os Estado não estariam submetidos a um poder comum (BOBBIO, 1991).
} 
de qualquer empreendimento humano.

Para Norberto Bobbio, esse estado de natureza não passava de uma hipótese da razão. Assim, segundo ele: "O que Hobbes quer dizer, falando de 'guerra de todos contra todos', é que, sempre onde existirem as condições que caracterizam o estado de natureza, este é um estado de guerra de todos os que nele se encontrarem" (BOBBIO, 1991, p. 36).

Portanto, a sua construção teórica se preocupou essencialmente com a antítese existente entre a unidade em torno de um único poder soberano e a anarquia social, presente nos lugares onde o poder se encontrava completamente fragmentado. A dissolução da autoridade, a desordem causada pela liberdade de discordar sobre o justo e o injusto, a fragmentação política causada pela idéia de que o poder deveria ser limitado, apareciam em Hobbes como questões prejudiciais para a boa formação da sociedade política, já que a escassez de poder, presente nestes ideais, poderia levar as pessoas a insegurança e a morte. Assim, em concordância com Hobbes, apenas a constituição de um poder comum, capaz de monopolizar o uso da força, teria condição de salvar os homens de sua própria destruição, já que somente com a superação do estado de natureza, o homem encontraria sua necessária libertação e salvação.

\section{AMODERNIDADE E O PENSAMENTO FILOSÓFICO DE THOMAS HOBBES}

A modernidade foi aberta por eventos de extraordinária repercussão: a reforma protestante, a chegada dos europeus à América, o humanismo renascentista, a revolução científica, o racionalismo de Descartes e o empirismo de Francis Bacon. No aspecto epistemológico, a concepção teológica do mundo foi substituída paulatinamente por outros fundamentos filosóficos e científicos, baseados principalmente no sujeito da modernidade. Segundo Nicola Matteucci, o processo de secularização da cultura e da política fez com que o constitucionalismo moderno desse maior consistência cultural ao antropocentrismo, afastando-se cada vez mais do elemento religioso enquanto fundamento para suas construções teóricas (MATTEUCCI, 1998).

Nesse sentido, o nascimento do sujeito foi um elemento determinante para a formação do pensamento de Thomas Hobbes, já que a valorização do indivíduo e de um tipo de certeza matemática, produzidas pela filosofia, tornaramse extremamente importantes para a formação de sua filosofia política. De acordo com Lenio Streck, "antes da vigorosa ruptura filosófica operada por 
Descartes - que é quem institui a modernidade filosófica - o conceito de sujeito cobria uma outra esfera de significados" (STRECK, 2011, p. 172), com o hipokeimenon aristotélico e o sub-jectum medieval. No período clássico, a metafísica afirmava que o sentido encontrava-se nas próprias coisas, já que em todas elas havia uma essência. Mas foi a partir da modernidade, com a superação do objetivismo presente na metafísica clássica, que o homem deixou de se sujeitar as estruturas e passou a assujeitar às coisas, fazendo com que o mundo passasse a ser explicado por meio da razão (STRECK, 2010). Desse modo, o surgimento do sujeito moderno marcou a ruptura com a metafísica clássica e alterou completamente a relação entre sujeito e objeto, ao permitir o aparecimento da subjetividade assujeitadora das coisas, já que os sentidos não estariam mais aprisionados nas próprias coisas, mas sim na mente (filosofia da consciência), constituindo uma expressão fundamental para uma nova atitude do homem em face da natureza e do próprio homem. Assim, a partir dessas transformações paradigmáticas, é possível compreender como se deu a elaboração do Estado Leviatã hobbesiano.

Hobbes alimentava grande aversão por Aristóteles e pela filosofia escolástica, e procurou se distanciar completamente das influências dos antigos e dos medievais, ao adotar uma postura crítica com relação à metafísica, chamada por ele de Empusa (monstro do inferno que assumia formas diferentes para atrair suas vítimas). Se para Aristóteles a filosofia não procurava realizar nada, a não ser um conhecimento contemplativo das coisas; para Hobbes a filosofia era de máxima utilidade para os homens, desde que procurassem aplicar as normas científicas a moral e a política, o que consequentemente tornaria possível a superação das guerras civis e das calamidades que tanto ensanguentavam a Inglaterra do século XVII. Dessa forma, a nova definição de filosofia, em Thomas Hobbes, não se ocupava de Deus ou do que inspirava a revelação divina, que no caso deveria pertencer exclusivamente ao ramo da fé, mas tinha por objeto os corpos, suas causas e suas propriedades, excluindo tudo o que é essência espiritual.

Segundo Giovane Reale e Dario Antiseri, a divisão hobbesiana da filosofia ocorria da seguinte maneira: "Ela (filosofia) deve tratar: a) do corpo em geral, b) do homem e c) do cidadão e do Estado. Foi com base nessa tripartição que Hobbes concebeu e elaborou a sua célebre trilogia De corpore, De homine e De cive" (REALE; ANTISERI, 1990b, p. 489).

Nesse mesmo sentido, Hobbes precedia a abordagem dos corpos de uma lógica que se remetia a tradição nominalista da filosofia inglesa, 
estabelecendo as regras do modo correto de pensar, que, nesse contexto, acabava por voltar-se mais para o nome do que para o pensamento. É importante ressaltar que essa influência veio principalmente de Guilherme de Ockham, que buscava trabalhar com os nomes a partir da inexistência dos universais nas coisas, sustentando a impossibilidade de qualquer relação direta entre nomes e objetos. Ele afirmava que os nomes comuns não indicavam conceitos universais, mas só existiam indivíduos e conceitos de indivíduos (nomes de nomes), referindose apenas ao que nós pensamos sobre as coisas.Ao assumir esse posicionamento, Ockham concedeu a linguagem um novo tratamento, abandonando a obscuridade em que ela havia sido relegada durante toda a metafísica clássica.

Para Hobbes essa posição se tornou fundamental nas questões políticas relacionadas à formação do Estado Leviatã, pois suas construções teóricas sempre asseguravam um papel essencial a linguagem, no sentido de constituir um elemento vital para o desenvolvimento das relações sociais e políticas. Desse modo, segundo Sergio Wolmann (1993, p. 30) "Sem linguagem não haveria entre os homens nem Estado, nem sociedade, nem contrato, nem paz, tal como não existem entre leões, os ursos e os lobos". Assim, Hobbes procurou romper com as posições metafísico-essencialistas que vigoraram durante todo o período clássico e escolástico, ao apresentar outra postura teórica para sustentar a origem convencional do Estado e do poder.

De acordo com Santos (2009, p. 91):

Em Hobbes, da mesma forma que em Ockham, as noções de justo e de direito resumem-se a termos que só têm sentido quando referidos às vontades e aos apetites dos indivíduos, únicas realidades atuais, ou como produtos de uma criação arbitrária do príncipe; um nominalismo para o qual estruturas ou totalidades diversas dos indivíduos só podem ser consideradas como criações artificiais.

A partir dessa posição, Hobbes sustentou que os elementos do edifício científico eram compostos por nomes, com a proposição constituída pela adição de dois nomes, o silogismo formado pela adição de duas proposições e a demonstração composta pela adição de vários silogismos, fazendo com que o ato de raciocinar fosse transformado num cálculo de somar e subtrair, numa concepção próxima a atividade dos aritméticos e dos geômetras. Nesse sentido, Hobbes chegou a se aproximar do racionalismo de René Descartes, que apresentou sua nova metodologia como uma forma mais segura para a aquisição do conhecimento, ao pretender fundamentar a possibilidade de conhecimento 
científico numa verdade inquestionável, capaz de refutar completamente o ceticismo. No entanto, é preciso destacar que esta aproximação não ocorreu de maneira absoluta, pois, ao contrário de Descartes, que partia de verdades primeiras para garantir a objetividade das estruturas do conhecimento, Hobbes procurava esvaziar esta pretensa objetividade ao se deslocar para o plano do convencionalismo (REALE; ANTISERI, 1990b).

Mais a maior influência recebida pelo pensamento hobbesiano veio do empirismo de Francis Bacon e da ciência moderna de Galileu. O empirismo inglês, juntamente com o racionalismo, foi um dos paradigmas fundamentais da primeira fase da filosofia moderna (XVI - XVIII), caracterizada principalmente pelo reconhecimento da experiência sensível como principal fonte de conhecimento e por uma concepção que partia primeiramente do método indutivo. Com Bacon, Hobbes passou a diferenciar o conhecimento inspirado pela revelação divina do conhecimento adquirido pelos sentidos, com a confiança de que apenas o último tipo de conhecimento teria condições de melhorar o mundo.

As transformações provocadas pela ciência moderna também deixaram marcas no pensamento hobbesiano, principalmente com Galileu e seu método de Pádua, que procurava analisar as coisas em elementos primeiros, para depois recompô-las e melhor compreender a gênese dos fenômenos. A partir desses conhecimentos adquiridos na física galileana, Hobbes procurou transpor para a filosofia política o método de Pádua, colocando-se em oposição ao modelo de ciência contemplativa que havia prevalecido entre os antigos. Nesse sentido, se para Hobbes a filosofia natural havia contribuído para o nascimento e desenvolvimento das artes mecânicas e, consequentemente, promovido uma melhora significativa na vida do homem; a filosofia política poderia ensinar aos homens a constituição de um bom Estado e, ao mesmo tempo, informar as principais lições da arte de governar bem, pois, segundo ele, a maior causa do mal e da perturbação social, deveria ser buscada fundamentalmente nas ideias sediciosas e falsas opiniões dos homens a respeito dos direitos e deveres dos soberanos e dos súditos (BOBBIO, 1991).

Hobbes buscou na filosofia o remédio para os problemas que afligiam a sociedade política, ao aproximar-se do sucesso das ciências naturais para encontrar o método mais bem elaborado no estudo das ciências morais. Para Hobbes, as causas dos conflitos sociais estavam concentradas principalmente na disparidade de opiniões na filosofia política, considerada por ele a maior responsável pela perturbação social entre os homens, já que estas dissensões 
demonstravam claramente a necessidade de transformar a ciência política numa ciência mais rigorosa, do mesmo modo que a geometria euclidiana havia feito com as ciências demonstrativas, ao acabar com as disputas inúteis e permitir que os homens alcançassem conclusões indiscutíveis.

Desse modo, ao tentar construir uma ciência política mais rigorosa, Hobbes se opôs frontalmente as posições filosóficas presentes na metafísica clássica, criticando o modelo especulativo de ciência oferecido pelo pensamento aristotélico, onde a ética e a política não eram apresentadas como conhecimento do certo, mas apenas como conhecimento do provável. Ao mesmo tempo, sua crítica também se estendeu aos escolásticos, já que estes procuravam fundamentar seus pensamentos na autoridade dos filósofos antigos (principalmente Platão e Aristóteles). Portanto, a construção teórica do Estado Leviatã, como produto da razão e da vontade dos indivíduos, exigiu essa forte critica a tradição do pensamento metafísico clássico, para que as conquistas da ciência moderna galileana e da geometria euclidiana também conquistassem a filosofia moral e a ciência política, superando os resquícios do pensamento científico especulativo ainda presentes no início da modernidade.

\section{CONSIDERAÇÕES FINAIS}

O Estado Leviatã foi uma resposta aos conflitos políticos e religiosos do século XVII, que, naquele momento, ameaçavam dissolver a estrutura de poder existente na Inglaterra. O radicalismo cristão, presente na atuação de diversas facções religiosas, e a divisão política existente entre defensores da prerrogativa do rei e partidários do parlamento, deixavam a sociedade inglesa numa verdadeira anarquia, fazendo com que as pessoas constantemente se encontrassem com medo e insegurança, frente a uma guerra civil que dilacerava seu próprio país. Diante desse contexto, Thomas Hobbes não teve como preocupação central o problema do abuso de poder, mais tarde analisado por diversos pensadores do constitucionalismo liberal, mas dedicou-se principalmente a atacar todas as teorias e ações políticas que procuravam comprometer a unidade do poder soberano, já que, para ele, a anarquia em que a sociedade inglesa se encontrava não era resultado do excesso de poder, mas sim uma consequência do problema da escassez de poder.

Por esse motivo, durante muito tempo sua obra foi mal compreendida por alguns críticos, sendo apontada como uma teoria totalmente despreocupada com a situação dos súditos. Na verdade, ao apresentar o Estado Leviatã como 
resposta aos diversos problemas e contradições que surgiram após a desintegração da sociedade feudal, Hobbes demonstrou uma grande preocupação com a situação real dos súditos, pois procurou defender a manutenção da vida por meio da criação de um poder soberano, considerado por ele como a única instituição com capacidade política e militar para combater a insegurança e a guerra generalizada, causadas fundamentalmente pela fragmentação do poder soberano. Foi por esse motivo que Hobbes se preocupou com o problema da dissolução do poder estatal, pois, diante desta situação, as pessoas se encontravam numa condição de completo impedimento para desenvolver qualquer empreendimento.

Desse modo, como observador despreconceituoso e distante de qualquer envolvimento direto com as organizações políticas e facções religiosas de sua época, Hobbes assistiu atentamente a realização de um grande evento da modernidade: o nascimento do Estado absolutista. Foi em defesa dessa conquista da modernidade que Hobbes apresentou o Leviatã, ao enfrentar os problemas sócio-políticos que mais prejudicavam a unidade do poder soberano, que, segundo ele, estava presente até mesmo nos conflitos de ideias existentes na sociedade inglesa.

De acordo com Hobbes, uma das causas mais importantes dos conflitos sociais estava concentrada na variedade de opiniões no campo da filosofia política, considerada por ele a maior responsável pela perturbação social. Esta situação exigia a transformação da ciência política numa ciência mais rigorosa, do mesmo modo que a geometria euclidiana havia feito com as ciências demonstrativas, acabando com as disputas improfícuas e permitindo que os homens alcançassem conclusões indiscutíveis. Nesse sentido, o nascimento do sujeito foi um elemento fundamental para a formação do pensamento de Thomas Hobbes, já que a valorização do indivíduo e de um tipo de certeza matemática, produzidas pela filosofia, tornaram-se extremamente importantes para a formação de sua filosofia política.

Dessa forma, Hobbes buscou na filosofia a solução para os problemas que assolavam a sociedade política, aproximando-se do sucesso das ciências naturais para encontrar o método mais bem elaborado para o estudo das ciências morais, já que, do mesmo modo que a filosofia natural havia contribuído para o nascimento e desenvolvimento das artes mecânicas, promovendo uma melhora significativa na vida do homem; Hobbes esperava que a filosofia política também pudesse proporcionar uma melhora significativa na vida das pessoas, ao ensinar 
o caminho correto para a constituição de um bom Estado.

Assim, a partir dos principais acontecimentos políticos, sociais e filosóficos do século XVII, é possível compreender a importância do Estado Leviatã para o desenvolvimento da filosofia política. Ao pensar e teorizar sobre os primeiros Estados absolutistas, Hobbes apenas defendeu a ideia de um poder exercido de forma absoluta, acima das contradições políticas e religiosas de seu tempo, pois, segundo ele, onde não houvesse poder comum não poderia prevalecer à lei e a ordem, mas apenas a morte, o caos e a destruição.

\section{REFERÊNCIAS}

ANDERSON, Perry. Linhagens do estado absolutista. São Paulo: Brasiliense, 2004.

BETHENCOURT, Francisco. História das inquisições: Portugal, Espanha e Itália: séculos XV e XVI. São Paulo: Companhia das Letras, 2000.

BOBBIO, Norberto. O positivismo jurídico: lições de filosofia do direito. São Paulo: ed. Ícone, 2006.

. Thomas Hobbes. Rio de Janeiro: Editora Campus, 1991.

CHEVALLIER, Jean-Jacques. As grandes obras políticas de Maquiavel a nossos dias. 8. ed. Rio de Janeiro: Agir, 1999.

FAORO, Raymundo. Os donos do poder: formação do patronato político brasileiro. 3. ed. São Paulo: Globo, 2001.

HOBBES, Thomas. Leviatã ou matéria, forma e poder de um estado eclesiástico e civil. 2. ed. São Paulo: Abril Cultural, 1979.

Jó. In: Bíblia sagrada. 3. ed. São Paulo: Geográfica, 2004. p. 530.

KOSELLECK, Reinhart. Crítica e crise: uma contribuição a patogênese do mundo burguês. Rio de Janeiro: Eduerj: Contraponto, 1999. 
LOPES, José Reinaldo de Lima. O direito na história: lições introdutórias. 3. ed. São Paulo: Atlas, 2009.

MATTEUCCI, Nicola. Organización del poder y liberdad: historia del constitucionalismo moderno. Madrid: Trotta, 1998.

REALE, Giovane; ANTISERI, Dario. História da filosofia I: do romantismo até nossos dias. São Paulo: Paulus, 1990a.

. História da filosofia II: do romantismo até nossos dias. São Paulo: Paulus, 1990b.

RIBEIRO, Renato Janine. Ao leitor sem medo: Hobbes escrevendo contra seu tempo. São Paulo: Brasiliense, 1984.

SANTOS, André Leonardo Copetti. Elementos de filosofia constitucional. Porto Alegre: Livraria do Advogado, 2009.

STRECK, Lenio Luiz. Hermenêutica jurídica e(m) crise.10. ed. Porto Alegre: Livraria do Advogado, 2011.

Livraria do Advogado, 2010.

O que é isto: decido conforme minha consciência? Porto Alegre:

WEBER, Max. Economia e sociedade: fundamentos da sociologia compreensiva. São Paulo: Editora UNB, 2004. v. 2.

WOLMANN, Sergio. O conceito de liberdade no Leviatã de Hobbes. Porto Alegre: Edipucrs, 1993.

Artigo recebido em: 26/06/2014 Aprovado para publicação em: 16/10/2014

Como citar: LIMA, Danilo Pereira. O Nascimento do Leviatã: Uma Análise do Estado Absolutista A Partir De Thomas Hobbes. Revista do Direito Público. Londrina, v.10, n.1, p.9-30, jan./abr.2015. DOI: 10.5433/1980511X.2015v10n1p9. 